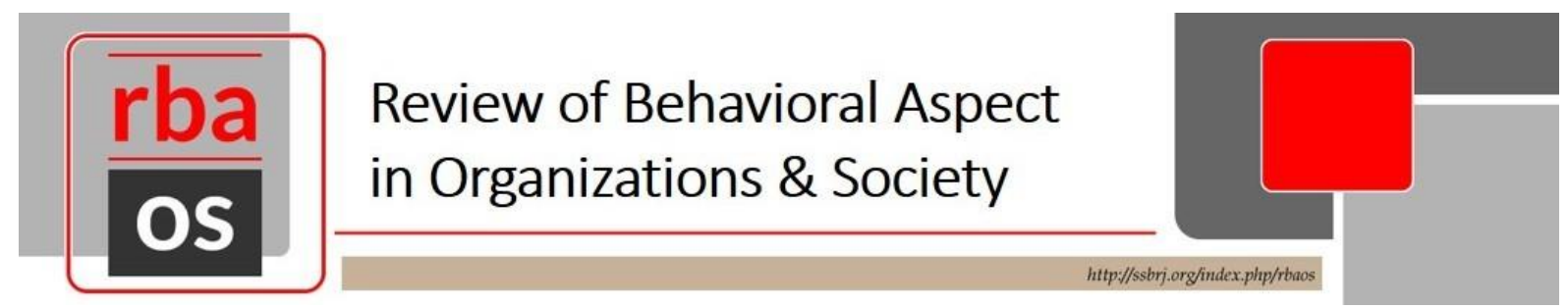

\title{
STRATEGIES FOR WOMEN'S EMPOWERMENT IN HOUSEHOLD INDUSTRIES IN THE PROVINCE OF SOUTH SULAWESI
}

\author{
Dwia Aries Tina Pulubuhu, Hasanuddin University, Indonesia \\ Sutinah, Hasanuddin University, Indonesia \\ Seni Wati, Hasanuddin University, Indonesia \\ Sri Suro Adhawaty, Hasanuddin University, Indonesia
}

\begin{abstract}
This study aims to analyze the financial feasibility of fishery product processing business in home industry scale, identifying and analyzing internal and external factors that influence women's low income in coastal communities and designing strategies to increase women's and family income in coastal communities. The data were analyzed by using the analysis of excellence, analysis of R/C ratio, and SWOT analysis. The results of the study showed that the level of financial feasibility of the women groups in product diversification processed in domestic processing industries needed to be developed. Therefore, strategies that can be applied for women's empowerment are increasing work motivation and skills to support the sustainability of the production, improving product quality and quantity to access broad market especially the export market, improving the government programs for women's empowerment, and conducting mentor and coach to improve the organization and product management quality, strengthening capital, partnerships, and networks for business development. This research can be implicated in a woman's business organization development strategies in order to sustain the business itself.
\end{abstract}

Keywords: strategy, empowerment, women, household industry 


\section{Background}

Empowerment is needed as an effort to provide opportunities for women's groups to design and carry out their businesses and make their own decisions for the development of their businesses. This empowerment is a part of the entrepreneur process that becomes the economic key in increasing and economic growth (Mukesh,2018). In this activity the empowerment model is implemented in kind of empowerment of the poor where they are not only actively participating in the process of ownership of the program, planning, and implementation, but also controlling the funds for the implementation of the program. Women and men have equal rights, obligations and opportunities in the development and each must be treated as an independent person that live together in the family, community, and nation that is characterized by a pattern of life and fair and balanced division of roles and responsibilities

Coastal community-fishermen is the most impoverished community in Indonesia. Furthermore it was stated that poverty was apparent in fishing communities in Indonesia as much as $78 \%$ of whom were fishermen laborers. However, different condition happens that is the product obtained is still relatively low, which in the end cannot meet the livelihoods and needs of fishermen's households. In line with that, the Sutinah et al. (2005) stated that the income of fishermen / fishermen laborers in South Sulawesi Province was still below the UMR (regional minimum wages), which was around Rp. 400,000 - Rp. 765,000 per month.

The poverty that occurs in third world countries such as Indonesia needs to get the attention of the government as a decision-maker. The role of women needs serious attention because of their involvement in various sectors (Sofer, 2013). This condition can support the Gender Equality and Justice Program (KKG) which is a global program especially in developing countries especially Indonesia. This is in line with the 1999 National Guidelines (GBHN). Also, it supports the Sustainable Development Goals focused on gender awareness through the women empowerment program (Pulubuhu at al. 2017).

Generally, women in coastal communities work in several aspects of activities, such as production, post-harvest, and fish marketing, housewives and community members, so women are faced with dilemma between their roles in the public and family, but fishermen's wives as small communities with low education turned out to be very productive in making a living because of the economic demands of the family. In connection with this statement, from the results of the research on ethnic Mandar by Farida (1993) stated that the allocation of time to make a living for wives, especially for ethnic Mandars, is quite high. The roles of women in families and activities to make a living are the implementation of role model of women that distinguishes Mandar ethnic from other ethnic groups in South Sulawesi Province,Indonesia.

Women in coastal communities, in general, have produced various of processed fishery products such as shredded fish, fish meatballs, thornless milkfish, brains, smoked fish, smoked sea cucumbers, seaweed syrup, candied seaweed, seaweed dodol, seaweed chips, seaweed sticks, seaweed beauty soap and much more. Unfortunately these products are only marketed locally but cannot go to the broad market such as the inter-island market, supermarkets, and export markets. There are several constraints that caused the processed fishery products cannot access the broad market. One of the constraints is they do not have a 
business permit such as $\mathrm{MOH}$ permit/ BPOM, halal certification from MUI (Indonesian ulama assembly), the packaging is not patent and hygienic, production is not sustainable, and lack of business capital. Specifically, there have been many capital assistance programs from the government that have been disbursed to empower coastal communities such as coastal community economic empowerment programs (PEMP), assistance programs for production equipment and so on, but the program is not yet optimal and sustainable, so that coastal communities today still in poor condition (Sutinah, 2007). This problem is related to competitiveness. It means, if they have low competitiveness they will not able to reach high business growth that will impact their welfare. Creativity and innovation are highly needed to improve business competitiveness (Harwiki et al., 2018).

Some large supermarkets in Makassar, such as Hypermart, Carrefour, Alfamaret, Indomart, none of them sell the processed fishery products originating from coastal communities in South Sulawesi province (Sutinah, 2010). Ironically, many fisheries products that are displayed in those supermarkets are processed products from abroad, such as Singapore, Malaysia, etc. One of the reasons the supermarket cannot sell local fishery products because it has low quality due to the lack of knowledge of coastal communities on appropriate technology, especially the fishermen families' (their wives and daughters) skills for processing and diversifying the food products to have higher economic value.

Based on the experimental condition, this research aims to analyze the financial feasibility of fishery product processing business in home industry scale, identify and analyze internal and external factors that influence women's low income in coastal communities, and design strategies to increase women's and family income in coastal communities. Besides, the implication of this research is useful in creating woman entrepreneurship, increasing family income and decreasing poverty in coastal communities.

\section{Research Method}

The location of this research and development was carried out in coastal areas in Takalar Regency, Maros Regency, Pangkep Regency, and Barru Regency. Location selection is purposive with the consideration that the areas have potential fishery products such as seaweed, shrimp, and fish. The type of this research is explanatory research through survey (Masrisingarimbun, 2004). This type of survey research is. Explanatory research is basic research that seeks to describe and explain a phenomenon and a condition that is studied as natural as it is and simultaneously explaining the background that causes the phenomenon and condition to happen (Supardi, 2005). The study was designed to explain the strategy of empowering women in home industries in South Sulawesi Province.

The population is all women involved in processing fishery products in home industries at the research locations. The sample was chosen by a purposive sampling technique which was deliberately chosen based on the business group that had been trained by non-governmental organizations (NGOs) as a comparison of selected business groups that had not received any training or in other word independent groups. Besides, there are sample groups consisting of entrepreneurs, cooperatives, formal and informal financial institutions, and related government and community leaders. For more details the number of respondents who are sampled will be presented in the following table.

From Table 1, it can be seen that each district has 9 household industry groups. There are more household industry groups that got training and couching by NGOs. However, only 9 of them are active in each district or 18 household industry groups in 2 districts taken as 
samples. Besides the household industry groups mentioned, there were also informants as respondents of this study that came from a financial institution. For this study, the informants were from Bank Rakyat Indonesia (BRI) as they were considered in accordance with their vision and mission to serve people to remote villages. For more details, see Table 2.

Table 1. The Number of Home Industry Groups in South Sulawesi in 2019 that became the Respondents of this Study

\begin{tabular}{ccc} 
No. & Regency/District & Number of Groups \\
\hline 1 & Maros & 9 \\
2 & Takalar & 9 \\
& Total number of groups & 18 \\
\hline
\end{tabular}

Source: Data processed, 2019

Tabel 2. Number of Respondents

\begin{tabular}{ccccccc}
\hline No. & District & $\begin{array}{c}\text { Financial } \\
\text { institution } \\
(\text { BRI })\end{array}$ & $\begin{array}{c}\text { Head of } \\
\text { a village }\end{array}$ & $\begin{array}{c}\text { Department of } \\
\text { marine and } \\
\text { fisheries }\end{array}$ & $\begin{array}{c}\text { Public } \\
\text { figure }\end{array}$ & Total \\
\hline 1 & 1 & 1 & 3 & 5 & 10 \\
2 & Maros & 1 & 1 & 3 & 5 & 10 \\
\hline & Takalar & 1 & 2 & 6 & 10 & 20 \\
\hline
\end{tabular}

Source: Primary data after processing, 2019

Besides enacting direct interviews with the respondents, a focus group discussion (FGD) was also conducted for the data collection to find solutions to problems in the home industry business group in each district. Besides, in order to analyze the financial and business condition, authors use:

Where:

$$
\pi \quad=\mathbf{T R}-\mathbf{T C}
$$

$\pi \quad=$ Net profit for fish processing business

$\mathrm{TR}=$ Total revenue

$\mathrm{TC}=$ Total cost

Where :

$$
\mathbf{T C}=\mathrm{VC}+\mathbf{F C}
$$

$\mathrm{VC}=$ Variable cost

$\mathrm{FC}=$ Fixed cost

To analyze the feasibility of home industry businesses managed by women, it is calculated by formula:

\section{$\mathrm{R} / \mathrm{C}$ ratio $=$ revenue $/$ cost $\times 100 \%$}


Where :

Revenue(R) : the amount of fish processing receipts for a certain period

Cost $(\mathrm{C}) \quad$ : the amount of costs used in a production cycle.

If $\mathrm{R} / \mathrm{C}>1$ : feasible to do; $\quad \mathrm{R} / \mathrm{C}<1:$ not feasible to do.

Tabel 3. SWOT Analysis Matrix

\begin{tabular}{l|l|l}
\hline \multicolumn{1}{|c|}{ Internal Factors } & \multicolumn{1}{|c}{$\begin{array}{c}\text { Strengths (S) } \\
\text { Determine internal } \\
\text { strength factors }\end{array}$} & \multicolumn{1}{|c}{$\begin{array}{l}\text { Weaknesses (W) } \\
\text { Determine internal } \\
\text { weaknesses factors }\end{array}$} \\
\hline $\begin{array}{l}\text { External Factors } \\
\begin{array}{l}\text { Opportunities (O) } \\
\text { Determine exportunity factors }\end{array}\end{array}$ & $\begin{array}{l}\text { SO Strategy } \\
\text { Devising strategies that } \\
\text { can utilize any chance to } \\
\text { become a strong point }\end{array}$ & $\begin{array}{l}\text { WO Strategy } \\
\text { Devising strategies that } \\
\text { can minimize the error } \\
\text { in utilizing the chance }\end{array}$ \\
\hline $\begin{array}{l}\text { Threats (T) } \begin{array}{l}\text { Determine external } \\
\text { threat factors }\end{array} \\
\begin{array}{l}\text { Devising strategies that } \\
\text { can overcome any threat } \\
\text { that can occur }\end{array}\end{array}$ & $\begin{array}{l}\text { Strategi WT } \\
\text { Devising strategies that } \\
\text { can minimize the } \\
\text { possibility of threat to } \\
\text { occur }\end{array}$ \\
\hline
\end{tabular}

Source: Rangkuti, 2017

\section{Findings}

SME's Group in Takalar Regency

Analysis of "Wati" Community SME's Business Profit

The "Wati" Community SME was chosen as an example because it has the biggest business profit and feasibility in Takalar Regency and the only SME that is engaged in fisheries with different commodities. In carrying out its business, the UKM "Wati" community uses mangosteen leaves to be made into tea. One production requires $2 \mathrm{~kg}$ of mangrove leaves and $1 \mathrm{~kg}$ of mint leaves. Average production activities are carried out once per month. Each 100 packs of mangrove leaf tea or kalli tea will be produced. The selling price of kalli tea is Rp. 20,000 per pack. The full selling value and business profits are as follows:

Table 4. Business Profit of "Wati" Comunity SME Per Month at 2018

\begin{tabular}{|l|c|c|c|c|c|c|}
\hline Month & TR & FC & VC & TC & $\prod$ & RC ratio \\
\hline Jan & $2,000,000$ & 229,167 & 105,000 & 334,167 & $1,665,833$ & 6.0 \\
\hline Feb & $2,000,000$ & 229,167 & 105,000 & 334,167 & $1,665,833$ & 6.0 \\
\hline Mar & $2,000,000$ & 229,167 & 105,000 & 334,167 & $1,665,833$ & 6.0 \\
\hline April & $2,000,000$ & 229,167 & 105,000 & 334,167 & $1,665,833$ & 6.0 \\
\hline May & $2,000,000$ & 229,167 & 105,000 & 334,167 & $1,665,833$ & 6.0 \\
\hline June & $2,000,000$ & 229,167 & 105,000 & 334,167 & $1,665,833$ & 6.0 \\
\hline July & $2,000,000$ & 229,167 & 105,000 & 334,167 & $1,665,833$ & 6.0 \\
\hline August & $2,000,000$ & 229,167 & 105,000 & 334,167 & $1,665,833$ & 6.0 \\
\hline Sept & $2,000,000$ & 229,167 & 105,000 & 334,167 & $1,665,833$ & 6.0 \\
\hline Oct & $2,000,000$ & 229,167 & 105,000 & 334,167 & $1,665,833$ & 6.0 \\
\hline Total & $20,000,000$ & $2,291,667$ & $1,050,000$ & $3,341,667$ & $16,658,333$ & \\
\cline { 1 - 5 } Average & $2,857,143$ & 327,381 & 150,000 & 477,381 & $2,379,762$ & \\
\hline
\end{tabular}

Source: Primary data after processing, 2019 
The average revenue from the sale of tea, as shown in table 3 is Rp. 2,857,143 per month. With total revenue as much as Rp.20.000.000 and the average of business profit is $\mathrm{Rp}$ $2,461,907$ per month.

In carrying out its activities, the "Wati" Community SME receives equipment from the MAP (Mangrove Action Project) as an OXFAM partner in the RCL project, including dryers, gloves, boots, blenders, filters, press machines, scissors, knives, and scales. The amount of assistance is calculated in depreciation costs. The conversion of depreciation costs from the value of assistance is calculated using the prevailing standard price of Rp. 2,803,300 per year or Rp. 260,415 per month.

Variable Cost is calculated from the value of the raw materials used, namely mangrove leaves and mint leaves. The price for mangrove leaves is converted from the costs incurred when taking mangrove leaves.

The production activities of the "Wati" Community UKM are not affected by the rising prices of some commodities in the market. Mangrove leaves as the primary raw material, available in nature in abundant quantities.

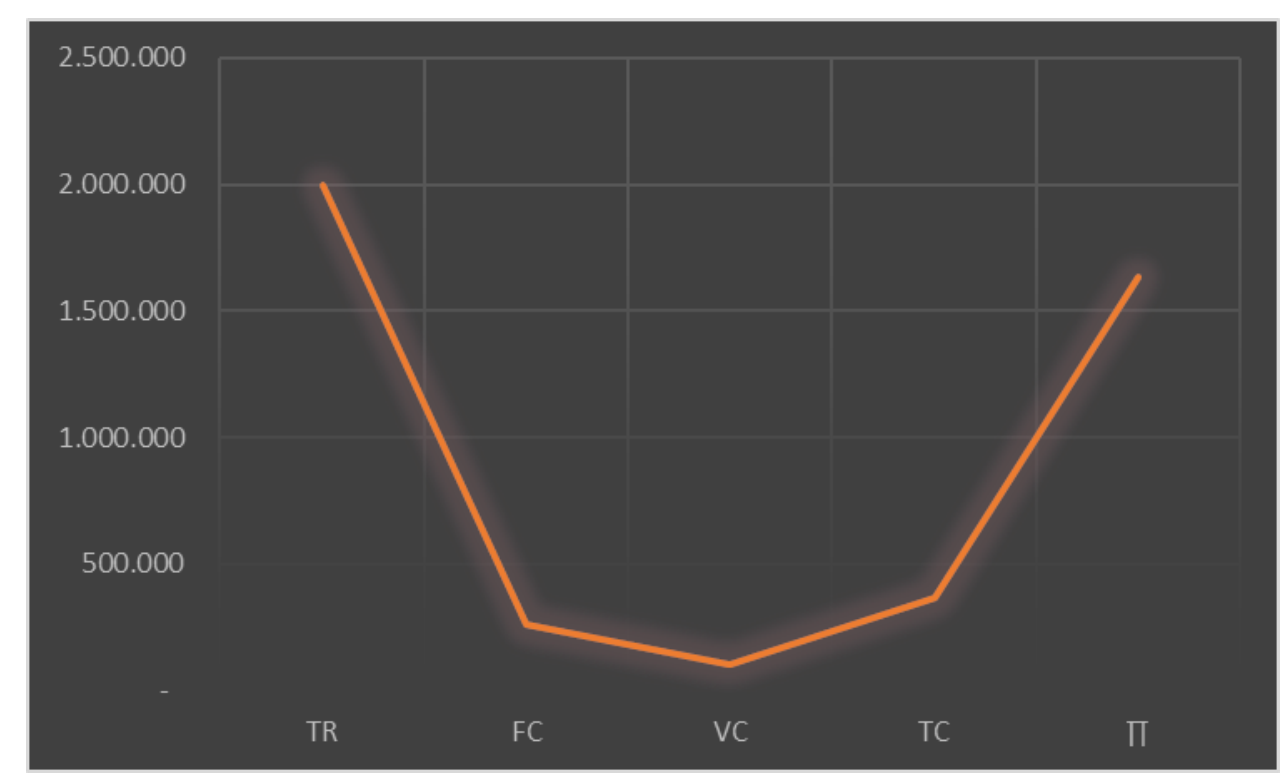

Figure 1. The Business Profit of "Wati" Community SME at 2018

In figure 1, it can be seen that there is no difference in the profits obtained before or after an increase in fuel price, which has an impact on the increase of some foodstuffs. The average $\mathrm{RC}$ business ratio before and after an increase in food prices is equal to 6 . The $\mathrm{R} / \mathrm{C}$ value is equal to 6 , giving the meaning that the business prospect is up-and-coming with an average profit of Rp 2,379,762; it can be used as a mainstay business as a source of income.

\section{Feasibility of Takalar Regency SMEs}

Takalar Regency has 9 SMEs that are sampled, the average profits obtained from business activities vary greatly, and there are even some SMEs that have $\mathrm{R} / \mathrm{C}$ values smaller than one as shown in the following table. 
Table 5. Average R/C Value TAKALAR Regency SMEs at 2018

\begin{tabular}{|l|l|l|c|c|c|c|}
\hline No & SMEs Name & Business Field & TR & C & $\prod$ & R/C \\
\hline 1 & Assamaturu & Seaweed & 140,000 & 73,778 & 66,222 & 1.9 \\
\hline 2 & Mutiara Putih & Seaweed/banana & 785,714 & 328,591 & 457,123 & 2.4 \\
\hline 3 & Jaya Sukses & Oyster/banana & 0 & 0 & 0 & 0.0 \\
\hline 4 & Melati Ayu & Crab & 42,857 & 50,024 & $-7,167$ & 0.9 \\
\hline 5 & Sipakainga & Crab/Fish & 193,000 & 168,117 & 24,883 & 1.1 \\
\hline 6 & Sipamalingmaling & Fish/Seaweed & 96,667 & 126,558 & $-29,892$ & 0.8 \\
\hline 7 & Citra Pesisir & Seaweed/Banana & 0 & 0 & 0 & 0.0 \\
\hline & & & & $2,335,11$ & \\
8 & "Wati" Community & Mangrove Leaf & $2,857,143$ & 522,024 & 9 & 5.5 \\
\hline 9 & Ahwat Sanro bone & Seaweed & 392,857 & 162,400 & 230,457 & 2.4 \\
\hline
\end{tabular}

Source: Primary data after processing, 2019

In Table 5, it can be seen that there are 2 SMEs that did not do any production activities throughout 2018, namely Jaya Sukses SME, which produces processed foods from shellfish and seaweed to be used as shellfish crackers and seaweed juice. Citra Pesisir SME which produces processed foods from seaweed and bananas to be used as sticks of seaweed and banana chips. The reason why Jaya Sukses SME did not do any production activity because in its production activities, Jaya Sukses is very dependent on orders. Jaya Sukses SME does not dare to produce continuously due to the absence of the market for its processed products. While Citra Pesisir does not produce more due to the failure of group management. Citra Pesisir SME is unable to turn back existing business capital so that for the next production activity, the capital is not available.

Four other SMEs have R / C values greater than one. Each of them, Assamaturu SME, has an $\mathrm{R} / \mathrm{C}$ value of 1.9, Mutiara Putih 2.4, "Wati" Community 5.5, and Ahwat Sanro Bone 2.4. The magnitude of the four R / $\mathrm{C}$ values of the UKM explained that these four SMEs have excellent prospects, and are very feasible to develop. Especially the "Wati" Community SME that uses mangrove leaves and does not have similar processed food products as competitors.

\section{SMEs Group in Pangkep Regency}

"Berkah" SME's Business Profit

"Berkah" SME is an example because it has the most prominent advantages and feasibility in Pangkep Regency, Berkah SME is engaged in fisheries production using seaweed as the primary raw material. There are three types of processed products, which are snacks, chips, and doi doi. One production for all three types of processed seaweed requires $1 \mathrm{~kg}$ seaweed. The average production activities are carried out four times per month. Per one-time production produces 35 packs of snacks, 35 packs of chips, and 19 packs of doi doi. The selling price of snacks per pack is IDR 10,000, chips IDR 4,000 per pack, and doi doi IDR 10,000 per pack. The total sales value and business profits are as follows.

In table 6 , it can be seen that the average total business income is Rp. $1,360,000$, greater than the total costs incurred for production activities. Business activities carried out provide significant benefits. During its business, berkah SME has never received any assistance. The 
business fixed cost of Rp. 455,000 is calculated from the depreciation of investment used in business activities.

Table 6. "Berkah" SME business profit per- month at 2018

\begin{tabular}{|l|c|l|l|l|l|l|}
\hline Month & \multicolumn{1}{|c|}{ TR } & \multicolumn{1}{c|}{ FC } & \multicolumn{1}{c|}{ VC } & \multicolumn{1}{c|}{ TC } & $\Pi$ & R/C \\
\hline Jan & $1,360,000$ & 455,000 & 169,000 & 624,000 & 736,000 & 2.2 \\
\hline Feb & $1,360,000$ & 455,000 & 169,000 & 624,000 & 736,000 & 2.2 \\
\hline Mar & $1,360,000$ & 455,000 & 169,000 & 624,000 & 736,000 & 2.2 \\
\hline Apr & $1,360,000$ & 455,000 & 169,000 & 624,000 & 736,000 & 2.2 \\
\hline May & $1,360,000$ & 455,000 & 169,000 & 624,000 & 736,000 & 2.2 \\
\hline Jun & $1,360,000$ & 455,000 & 181,500 & 636,500 & 723,500 & 2.1 \\
\hline Jul & $1,360,000$ & 455,000 & 181,500 & 636,500 & 723,500 & 2.1 \\
\hline Aug & $1,360,000$ & 455,000 & 181,500 & 636,500 & 723,500 & 2.1 \\
\hline Sep & $1,360,000$ & 455,000 & 181,500 & 636,500 & 723,500 & 2.1 \\
\hline Oct & $1,360,000$ & 455,000 & 181,500 & 636,500 & 723,500 & 2.1 \\
\hline Total & $13,600,000$ & $4,550,000$ & $1,752,500$ & $6,302,500$ & $7,297,500$ & \\
\hline Avg & $1,360,000$ & 455,000 & 175,250 & 630,250 & 729,750 & \\
\hline Source
\end{tabular}

Source: Primary data after processing, 2019

Variable costs are calculated from the value of raw materials used; the increase in fuel prices does not affect business profits. The profits obtained after the increase in fuel prices are almost the same as the profits obtained before the increase in fuel prices as illustrated in the following graph.

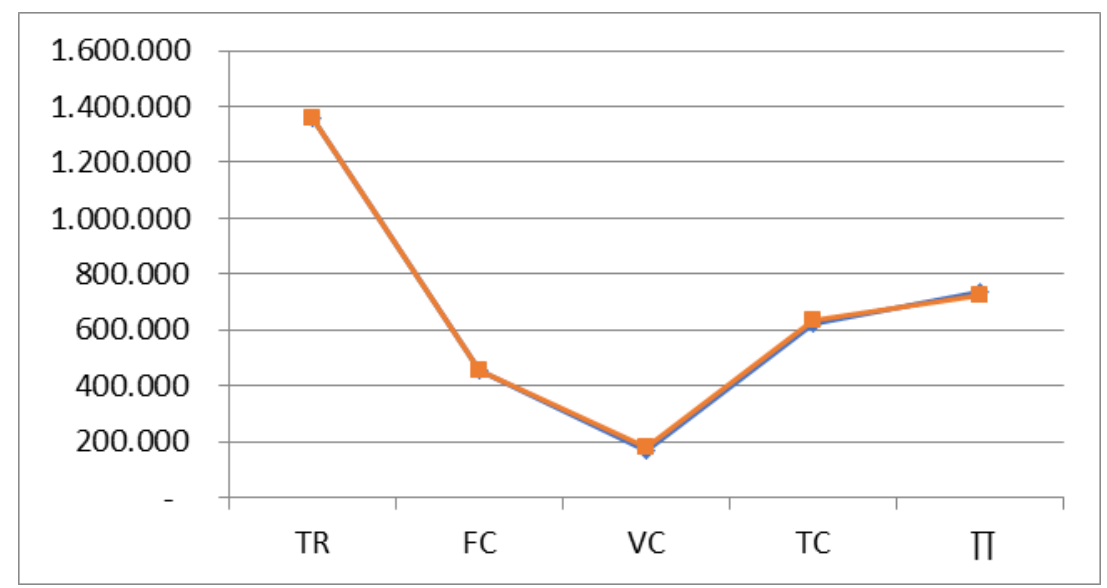

Figure 2. The Business Profit of "Berkah" Community SME at 2018

The cost variable after the increase in fuel prices is almost the same as the cost variable before the increase in fuel prices. The same goes for the total cost and business profits. The value of $\mathrm{R} / \mathrm{C}$ before the increase in fuel prices is 2.2 , only down 0.1 digits after the increase in fuel prices is equal to 2.1 . With an $\mathrm{R} / \mathrm{C}$ of 2.1 , this business is very feasible to develop because it has excellent business prospects.

The data in Table 7 explains that there is one SME that no longer do any production activities throughout 2018, namely the "Ashura" SME. The non-production of "Ashura" SME was partly due to the ineffectiveness of the group's management, and it gave impact on the death of all the laying ducks provided by Oxfam assistance. "Magfirah" SME with four types of processed seaweed products, although the production frequency is quite high, the high cost of 
business variables causes low profits. With an R / C ratio, an average of 1. "Magfirah" SME should focus more on just one or two more prospective products. Many types of processed products cause the total cost of the business to be large. The same goes for "Kalaroang" SME. To be able to survive and develop, "Kaloroang" SME needs to make cost efficiency. 6 (Six) other SMEs with an average R / C value greater than one. Each of them, Abon Ikan Bandeng SME 1.3, Sipurennu SME 1.5, Pita Aksi SME 1.6, Berkah SME 2.2, rejeki SME 1.7, and Nilasari SME 1.4. have excellent prospects and are very feasible to be developed.

Table 7. Average R/C value of SMEs in PANGKEP Regency at 2018

\begin{tabular}{|l|l|l|l|l|l|}
\hline No & SMEs & TR & TC & $\prod$ & RC ratio \\
\hline 1 & Abon I. Bandeng & $2,000,000$ & $1,506,167$ & 493,833 & 1.33 \\
\hline 2 & Magfirah & 460,000 & 438,467 & 21,533 & 1.05 \\
\hline 3 & Sipurenno & $3,000,000$ & $2,046,852$ & 953,148 & 1.47 \\
\hline 4 & Pita sari & 332,350 & 212,750 & 119,600 & 1.56 \\
\hline 5 & Asyurah & - & - & - & - \\
\hline 6 & Berkah & $1,360,000$ & 630,250 & 729,750 & 2.16 \\
\hline 7 & Rejeki & 600,000 & 349,403 & 250,597 & 1.72 \\
\hline 8 & Nilasari & 450,000 & 316,700 & 133,300 & 1.42 \\
\hline 9 & Kalaroang & 875,000 & 905,183 & $(30,183)$ & 0.97 \\
\hline
\end{tabular}

Source: Primary data after processing, 2019

SWOT Analysis

Table 8. SWOT Analysis of Household Industrial Food Processing Businesses in South Sulawesi Province

\begin{tabular}{|c|c|c|}
\hline EFE & $\begin{array}{l}\text { STRENGTH } \\
\text { 1. High work motivation } \\
\text { 2. Productive age } \\
\text { 3. Number of the } \\
\text { workforce is a lot } \\
\text { 4. Raw materials available } \\
\text { 5. Product quality is good. } \\
\text { 6. The results of processed } \\
\text { products that are quite } \\
\text { specific or unique } \\
\text { 7. Work time is quite spare, } \\
\text { especially for women }\end{array}$ & $\begin{array}{l}\text { WEAKNESS } \\
\text { 1. More qualified competitor } \\
\text { products } \\
\text { 2. The high demand of } \\
\text { consumers for quality food } \\
\text { products } \\
\text { 3. A free market that allows } \\
\text { imported products including } \\
\text { processed food to enter } \\
\text { Indonesia } \\
\text { 4he level of consumer } \\
\text { protection is quite high by } \\
\text { various standardization } \\
\text { institutions, making it } \\
\text { possible for community } \\
\text { processed products to be } \\
\text { more difficult to accept }\end{array}$ \\
\hline $\begin{array}{l}\text { OPPORTUNITIES } \\
\text { 1. High demand for } \\
\text { processed food } \\
\text { products, especially } \\
\text { fishery products } \\
\text { 2. Government attention is } \\
\text { high enough for }\end{array}$ & \begin{tabular}{|l} 
SO STRATEGY \\
1. Increase work \\
motivation and skills to \\
support sustainable \\
production \\
2. Increase product quality \\
and quantity to access a
\end{tabular} & $\begin{array}{l}\text { WO STRATEGY } \\
\text { 1. Strengthening capital to } \\
\text { improve product quality } \\
\text { 2. Establish partnerships and } \\
\text { strengthen networks } \\
\text { 3. The assistance program for } \\
\text { production equipment should }\end{array}$ \\
\hline
\end{tabular}




\begin{tabular}{|c|c|c|}
\hline $\begin{array}{l}\text { business development } \\
\text { 3. Lifestyle diet for ready- } \\
\text { to-eat food products } \\
\text { 4. There are } \\
\text { encouragement and } \\
\text { concern from various } \\
\text { institutions for the } \\
\text { advancement and } \\
\text { welfare of coastal } \\
\text { communities, both } \\
\text { government and private, } \\
\text { such as NGOs } \\
\text { 5. High export demand for } \\
\text { processed fishery } \\
\text { products }\end{array}$ & $\begin{array}{l}\text { broad market, especially } \\
\text { the export market. } \\
\text { 3. Increase the Ministry of } \\
\text { Maritime Affairs and } \\
\text { Fisheries program to } \\
\text { empower women } \\
\text { 4. Mentoring \& assistance } \\
\text { to women's groups need } \\
\text { to be intensified } \\
\text { 5. Fostering and } \\
\text { empowering resource- } \\
\text { based business groups } \\
\text { and the potential of their } \\
\text { respective regions } \\
\text { 6. Search and open } \\
\text { marketing networks by } \\
\text { creating specific } \\
\text { products with } \\
\text { standardized quality }\end{array}$ & $\begin{array}{l}\text { be evenly distributed and } \\
\text { according to the needs of the } \\
\text { group } \\
\text { 4. Improve product quality } \\
\text { according to quality } \\
\text { assurance standards (ISO) } \\
\text { through mentoring and } \\
\text { fostering program of the } \\
\text { Ministry of Maritime Affairs } \\
\text { and Fisheries } \\
\text { 5. Diversify products that are in } \\
\text { accordance with the needs } \\
\text { and prices affordable by } \\
\text { consumers }\end{array}$ \\
\hline $\begin{array}{l}\text { THREAT } \\
\text { 1. More qualified } \\
\text { competitor products } \\
\text { 2. The high demand of } \\
\text { consumers for quality } \\
\text { food products } \\
\text { 3. ASEAN and GLOBAL } \\
\text { free market } \\
\text { 4. The level of consumer } \\
\text { protection is quite high } \\
\text { by various } \\
\text { standardization } \\
\text { institutions, making it } \\
\text { possible for home } \\
\text { industry processed } \\
\text { products to be more } \\
\text { difficult to accept }\end{array}$ & $\begin{array}{l}\text { ST STRATEGY } \\
\text { 1. Strengthening } \\
\text { institutional SME groups } \\
\text { 2. Increasing assistance to } \\
\text { SME groups }\end{array}$ & $\begin{array}{l}\text { WT STRATEGY } \\
\text { 1. Conduct market research } \\
\text { 2. Developing product quality } \\
\text { and quantity }\end{array}$ \\
\hline
\end{tabular}

Source: Primary data after processed, 2019

\section{Conclusion}

1. The level of the financial feasibility of the food processing business of home industry products on average is greater than one; this indicates that the business is feasible to be developed.

2. Internal factors that influence business development are strengths and weaknesses, which consist of strengths, including; High work motivation, productive age, large number of workers, availability of raw materials, and good product quality. Whereas Weaknesses include lack of business capital, simple production equipment, simple packaging, high price of sophisticated production equipment, still local market access, no MUI halal certificate yet, no $\mathrm{MOH}$ permit yet, production is not continuous, production process has not been mastered evenly by group members, most groups do not have partners yet, and product prices are still low, so profits are low. 


\section{References}

Harwiki, W., Choiron, A., \& Hartini, S. (2018). Batik creative industry: Creativity, innovation and competitiveness to encounter global market. Journal of Business and Finance in Emerging Market, 1(2), 189-196.

Mukesh, H. V., \& Thomas, B. (2018). Developing and sustaining future entrepreneurial talent: A study of student entrepreneurial potential and achievement motivation. Journal of Business and Finance in Emerging Market, 1(2), 197-204.

Sutinah. 2007. Study of impact and solution of increase in fuel prices on fishing operations in Barru Regency, South Sulawesi, consortium of the South Sulawesi Regional Center maritime partner program. (translated from indonesia: kajian dampak dan solusi kenaikan harga BBM terhadap operasional penangkapan ikan di kabupaten Barru Sulawesi Selatan, konsorsium program Mitra Bahari Regional Center Sulawesi Selatan).

Sutinah. 2010. Analysis of fishermen's income on various fishing devices in South Sulawesi Province. Proceedings of the UGM National Marine And Fisheries Seminar in Yogyakarta. (translated from Indonesia: Analisis pendapatan nelayan pada berbagai alat tangkap di Provinsi Sulawesi Selatan. Prosiding seminar Nasional Kelautan dan Perikanan UGM Yogyakarta).

Sutinah, Mardiana, E. F., Hamzah, 2005. Development of Economic Institutional Models Needed by Fishermen Communities in South Sulawesi Province. LP UNHAS Balitbangda SUL-SEL. (translated from Indonesia: Pengembangan Model Kelembagaan Ekonomi yang Dibutuhkan Masyarakat Nelayan di Propinsi Sulawesi Selatan. LP UNHAS - Balitbangda SUL-SEL)

Sofer, M. (2013). Revisiting rural places: Pathways to poverty and prosperity in Southeast Asia. Australian Geographer, 44(4), 482-484.

Pulubuhu, T., Aries, D. SeniWati \& Alimuddin, A. 2017. Accomplishing the sustainable development goals as method in women confronting terrorism. Avensis and Social Sciences Education and Humanities Research (ASSEHR). 
